\title{
Adherence to the use of the surgical checklist for patient safety
}

\author{
Adesão ao uso de um checklist cirúrgico para segurança do paciente \\ Adherencia al uso del checklist cirúgico para seguridad del paciente
}

\author{
Eliane Cristina Sanches Maziero ${ }^{a}$ \\ Ana Elisa Bauer de Camargo Silva ${ }^{b}$ \\ Maria de Fátima Mantovanic \\ Elaine Drehmer de Almeida Cruz ${ }^{c}$
}

\section{ABSTRACT}

Objective: Evaluate adherence to the checklist of the Programa Cirurgias Seguras (safe surgery programme) at a teaching hospital. Methods: Evaluative study conducted at a teaching hospital in the south of Brazil in 2012. Data were collected by means of non-participant observation in 20 hip and knee replacement surgeries and an instrument that was created for research based on the checklist and used by the institution.

Results: In the observed procedures $(n=20)$ there was significant adhesion $(p<0.05)$ to the instrument in relation to the verification of documentation, fasting, hair removal in the surgical site, absence of nail varnish and accessories, identification of the patient and surgical site on admission to the surgical unit, availability of blood and functionality of materials. However, there was no significant adherence to the checklist in the operating room in relation to patient identification, procedure and laterality, team introduction, surgical break and materials count.

Conclusion: The results showed that the items on the checklist were verified nonverbally and there was no significant adherence to the instrument.

Keywords: Patient safety. Surgical procedures, operative. Program evaluation.

\section{RESUMO}

Objetivo: Avaliar a adesão ao checklist do Programa Cirurgias Seguras em um hospital de ensino.

Métodos: Pesquisa avaliativa desenvolvida em hospital de ensino do sul do Brasil em 2012. A coleta de dados foi realizada por meio de observação não participante de 20 cirurgias ortopédicas de prótese de quadril e joelho e norteada por instrumento elaborado para a pesquisa com base no checklist criado e utilizado pela instituição.

Resultados: Nos procedimentos observados $(n=20)$ houve adesão significativa $(p<0,05)$ em relação à verificação de documentação, jejum, tricotomia, ausência de esmalte e adornos, identificação do paciente e sítio operatório, disponibilidade de sangue e funcionalidade de materiais. Não houve adesão significativa à verificação da identificação do paciente, do procedimento e da lateralidade, da apresentação da equipe, da pausa cirúrgica e da contagem de materiais em sala operatória.

Conclusão: 0 estudo avaliou que a verificação dos itens do checklist se deu de forma não verbal e que não houve adesão significativa ao instrumento.

Palavras-chave: Segurança do paciente. Procedimentos cirúrgicos operatórios. Avaliação de programas e projetos de saúde.

\section{RESUMEN}

Objetivo: Evaluar la adherencia al check list del Programa Cirugías Seguras en un hospital de enseñanza.

Métodos: Investigación evaluativa desarrollada en un hospital de enseñanza en el sur de Brasil en 2012. La recolección de datos fue realizada mediante la observación no participante de 20 cirugías ortopédicas de la prótesis de cadera y rodilla, realizada con un instrumento desarrollado para la investigación basado en lista de verificación creado y utilizado por la institución.

Resultados: Los procedimientos observados ( $n=20)$ hubo adherencia significativa $(p<0,05)$ al instrumento en los aspectos de verificación de documentación, ayunas, tricotomía, ausencia de esmalte de uñas y adornos, identificación del paciente y sitio operatorio en la admisión en el centro quirúrgico, disponibilidad de sangre y funcionalidad de materiales. No hubo adherencia significativa a la verificación, en la sala de operaciones, de la identificación del paciente, procedimiento y lateralidad, presentación del equipo, pausa quirúrgica y al hecho de contar con materiales.

Conclusión: El estudio evaluó que la verificación de los ítems del check list se dio de forma no verbal y que no hubo adhesión significativa al instrumento.

Palabras clave: Seguridad del paciente. Procedimientos quirúrgicos operativos. Evaluación de programas y proyectos de salud.
D0l: $\quad$ http://dx.doi.org/10.1590/19831447.2015.04.53716

\footnotetext{
a Universidade Federal do Paraná (UFPR), Programa de Pós-Graduação em Enfermagem. Curitiba, Paraná (PR), Brasil.

${ }^{\mathrm{b}}$ Universidade Federal de Goiás (UFGO), Departamento de Enfermagem. Goiânia, Goiás (GO), Brasil.

' Universidade Federal do Paraná (UFPR), Departamento de Enfermagem. Curitiba, Paraná (PR), Brasil.
} 


\section{IINTRODUCTION}

The World Alliance for Patient Safety, created in 2004 by the World Health Organization (WHO), includes the Safe Surgery Saves Lives programme that aims to raise the standards of quality in healthcare services by establishing practices for safe surgery. The programme provides a checklist to assess the elements that are considered critical to patient safety ${ }^{(1)}$. The elements of this instrument were evaluated with 7,688 patients; 3,733 before and 3,955 after its institution. The results showed that the occurrence of major complications and deaths dropped from 11 to $7 \%$ and 1.5 to $0.8 \%$, respectively ${ }^{(2)}$. To support the implementation and use of the checklist, in 2009 the WHO launched a handbook with specific guidelines on how to use the instrument ${ }^{(3)}$.

This is considered essential for tasks that are known to be complex and repetitive, such as the routine tasks completed in the surgery unit, including equipment and anaesthesia checks, blood reserve checks, patient identification, team and patient confirmation of the type and site of surgery, and feedback at the end of the procedure to detect possible errors ${ }^{(4)}$.

In Brazil, in 2013, based on the recommendations of the $\mathrm{WHO}$, the Brazilian government launched the Programa Nacional de Segurança do Paciente, or the national programme for patient safety, that establishes actions to prevent and reduce the incidence of adverse events ${ }^{(5)}$.

For this same purpose, a study group at a teaching hospital in southern Brazil was created in 2010. This group supported the implementation of the safe surgery programme and the checklist, as recommended by the $\mathrm{WHO}$, and selected orthopaedics as the pilot speciality. National and international studies have identified difficulties in the use of the checklist.

A study conducted in Brazil showed that the biggest problems related to adherence to the checklist were during the stages prior to induction of anaesthesia and prior to the surgical incision. The authors concluded that the purpose and the correct way to complete the checklist must be demonstrated during the implementation period $^{(6)}$. At five British hospitals, $40 \%$ of the team was absent at the time of checking the items, and in more than 70\% of the cases the required pause to check the items was not observed ${ }^{(7)}$. Also in England, a study with ten hospitals revealed that senior physicians have great difficulty in adhering to the checklist, which negatively reflects on the rest of the team ${ }^{(8)}$.

Consequently, the object of this study is the safe surgery programme that is being implemented at the institu- tion based on the following guiding question: What is the rate of adherence of the members of the team of hip and knee replacement surgery to the checklist used in the institutional safe surgery programme?

The aim of this paper is to assess adherence to the checklist of the safe surgery programme at a teaching hospital, which is justified by the high global incidence of potentially preventable adverse events during surgery. The use of the checklist helps to remind the health team of instructions that guarantee patient safety ${ }^{(4)}$. However, adherence to new verification instruments is a challenge because they must be incorporated into the care routine. Considering that the identification of non-conformities in processes and procedures helps detect risk situations and plan strategies for the continuous improvement of care processes ${ }^{(5)}$, this study supports the enhancement of nursing and medical care within the context of care of the surgical patient.

\section{METHOD}

A study based on evaluative research that enables the trial and performance of an intervention, and leads to results that support decision-making ${ }^{(9)}$. In this study, the intervention was characterized as the checklist adopted by the safe surgery programme in the main surgery unit of a teaching hospital in southern Brazil, and the evaluation targeted adherence to this instrument by the surgical team.

The programme started as a pilot in 2011 in the speciality of orthopaedics. The board of the institution chose to adopt the checklist, which was prepared and applied according to the model recommended by the WHO. The institutional checklist consists of four steps: patient reception, prior to the induction of anaesthesia, prior to surgical incision and prior to the patient's removal from the operating room.

The sample was composed of 20 hip and knee replacement procedures and the observation of 22 professionals during the procedures. The choice of surgery is justified due to the complexity and scale, and the laterality, thus representing a greater risk of adverse events. This procedure is also part of a groundbreaking speciality of the safe surgery programme at the teaching institution. The verification and completion of all the items on the checklist for the four application stages, according to the selected model, were considered variables of the study.

The size of the population $(N)$, the expected proportion of checklist completion ( $p$ ), the margin of error $(E)$ and the level of confidence $(z)$ were considered to calculate the sample $(n)$, based on the sample proportion formula ${ }^{(10)}$ : 


$$
n=\frac{N p(1-p) z^{2}}{p(1-p) z^{2}+(N-1) E^{2}}
$$

After applying this formula, the sample size established for this study was 20 surgical procedures, considering that the estimated population size for the data period was 70 elective surgeries $(N)$ and that the estimated proportion of checklist completion ( $p$ ) was $4 \%$, based on the results of a previous pilot. The margin of error was $0.05(E)$ and the confidence level was $80 \%(z=1.28)$.

Data were collected from February to May 2012. The participants were invited to take part in the study at the surgery unit. After all the respective clarifications, they signed an informed consent statement. The inclusion criteria were hip or knee replacement surgery performed during the data collection period.

The researchers proceeded with the non-participant observation(11) used for data collection from patient transportation from the inpatient unit by the surgery team to patient removal from the operating room. A roadmap for non-participant observation was constructed for this study according to the institutional checklist. This roadmap allowed the researcher to record all the observations related to use of the checklist, the exact moment each item of the four stages of the list was checked, the professional who used the checklist, the type of verification (verbal or non-verbal) and the recording of each verification.

The data were entered into an Excel spreadsheet and subsequently arranged and processed using the EpiData programme version 3.1. These data were analyzed using descriptive statistics and the Program $R$ version $2011^{(12)}$. The statistical significance of adherence was tested using the completed checklist items and the uniformly most powerful test, which is indicated to analyze binomial variables (yes/no) ${ }^{(13)}$. For this study, the checklist items were considered completed (yes) and not completed (no). A proportion of completion of 50\% or less of the respective item was considered for the null hypothesis, while the completion of $50 \%$ or more of the respective item was considered for the alternative hypothesis. Evidence of adherence to a given checklist element was considered sufficient when the $p$-value of the statistical test was $<0.05$ (5\%). The items were repeated in the 20 surgeries. When 14 (70\%) or more verifications were detected, the respective item was considered statistically significant

The research for this study observed the ethical research standards involving human beings, and it was approved and registered by the Comitê de Ética em Pesquisa with protocol CEP/SD 1102.027.11.04.
The paper was extracted from the master's dissertation: "Avaliação da Implantação do Programa Cirurgia Segura em um Hospital de Ensino"(14).

\section{QRESULTS}

The checklist was used in the 20 observed surgeries. The results of completion, method and moment are presented and organized in four stages; the data for the first stage are presented in table 1.

Table 2 shows the results of the second stage of the observation, before the induction of anaesthesia.

The recommendation that all professionals introduce themselves to the patients was not fully observed and occurred as follows: in 100\% ( $n=20)$ of the procedures, the anaesthesiologist introduced himself to the patient; in $15 \%(n=3)$, the resident of anaesthesiology introduced himself; in 35\% ( $n=7)$, the nursing technician introduced himself; and in $5 \%(n=1)$, the nurse introduced himself to the patient. The surgeon, the surgical resident and the instrument nurse did not introduce themselves to the patients in any procedure.

The third stage of the checklist, prior to the surgical incision, also called surgical break or time out, should be applied immediately before the start of surgery. In this stage, the professionals interrupt their activities to confirm the checklist items with the participation of everyone in the operating room. The surgical break did not fully occur in any of the procedures. In $45 \%(n=9)$ of the procedures the items were checked after the surgical incision; in 20\% (n $=4$ ) of the procedures, the anaesthesiologist checked all items, although the verification was not verbal; and in $20 \%$ $(n=4)$ of the procedures, the nursing technician checked the items without the verbal confirmation of the other professionals. Table 3 shows the observation results of the third stage.

In the fourth stage of the checklist, before the patient was removed from the operating room, the observed procedures for all the surgeries were document checks (forms related to anaesthesia, procedure description, patient removal and orthoses and prostheses), the anatomical pathology request, and the registration of special recommendations for postoperative recovery. However, these verifications were not verbal. There was no observed verification of the items related to counting the instruments, needles, compresses and gauzes. In 15\% ( $n=3)$ of the procedures, the instruments were not counted when the instrument box was opened, in 15\% ( $n=3)$ of the procedures, the compresses were not counted when the packaging was opened, and in 100\% ( $n=20)$ of the cases, there was 
Table 1 - Adherence to the surgical safety checklist during the first verification stage - reception of the patient $(n=20)$. Curitiba, PR, 2012

\begin{tabular}{|c|c|c|c|c|}
\hline Observed variables & $\begin{array}{l}\text { Verbal verifica- } \\
\text { tion at the unit } \\
\text { of origin } \\
n(\%)\end{array}$ & $\begin{array}{l}\text { Verbal verifi- } \\
\text { cation during } \\
\text { reception at the } \\
\text { surgery unit } \\
\text { n (\%) }\end{array}$ & $\begin{array}{l}\text { Non-verbal ver- } \\
\text { ification during } \\
\text { reception at the } \\
\text { surgery unit } \\
n(\%)\end{array}$ & $\begin{array}{l}\text { Not verified during } \\
\text { reception at the } \\
\text { surgery unit and } \\
\text { registered } \\
\text { n (\%) }\end{array}$ \\
\hline Identification bracelet & $17(85)^{*}$ & - & $20(100)^{*}$ & - \\
\hline Chart & $18(90)^{*}$ & - & $20(100)^{*}$ & - \\
\hline Image scans & $18(90)^{*}$ & - & $20(100)^{*}$ & - \\
\hline Pre-anaesthesia assessment & $18(90)^{*}$ & - & $19(95)^{*}$ & $1(5)$ \\
\hline Surgery consent & $18(90)^{*}$ & - & $20(100)^{*}$ & - \\
\hline Anaesthesia consent & $18(90)^{*}$ & - & $20(100)^{*}$ & - \\
\hline Nursing assessment & $18(90)^{*}$ & - & $20(100)^{*}$ & - \\
\hline Surgical site marked & $18(90)^{*}$ & $9(45)$ & - & $1(5)$ \\
\hline Trichotomy & $18(90)^{*}$ & - & - & $2(10)$ \\
\hline Fasting & $18(90)^{*}$ & $9(45)$ & - & - \\
\hline Free of accessories and belongings & $18(90)^{*}$ & - & - & $2(10)$ \\
\hline Free of nail enamel & $18(90)^{*}$ & & - & $2(10)$ \\
\hline Free of prosthetics & $18(90)^{*}$ & - & - & $2(10)$ \\
\hline
\end{tabular}

${ }^{*} p<0.05$

Source: Research data, 2012.

Table 2 - Adherence to the surgical safety checklist during the second verification stage - prior to induction of anaesthesia $(n=20)$. Curitiba, PR, 2012

\begin{tabular}{lcccc}
\multicolumn{1}{c}{ Observed variables } & $\begin{array}{c}\text { Verbal } \\
\text { verification } \\
\mathbf{n ( \% )}\end{array}$ & $\begin{array}{c}\text { Non-verbal } \\
\text { verification } \\
\mathbf{n}(\%)\end{array}$ & $\begin{array}{c}\text { Not verified and } \\
\text { registered } \\
\mathbf{n}(\%)\end{array}$ & $\begin{array}{c}\text { Not verified and } \\
\text { not registered } \\
\mathbf{n}(\%)\end{array}$ \\
\hline Patient identity & $10(50)$ & $9(45)$ & $1(5)$ & - \\
Patient confirms the surgical site & $10(50)$ & $9(45)$ & $1(5)$ & - \\
Patient confirms surgery & $10(50)$ & $9(45)$ & $1(5)$ & - \\
Patient introduced to the team & - & - & $20(100)^{*}$ & - \\
Blood reserve & $1(5)$ & $18(90)^{*}$ & $1(5)$ & - \\
Surgical site marked and confirmed & $2(10)$ & $18(90)^{*}$ & - & - \\
Anaesthesia equipment tested & - & $20(100)^{*}$ & - & - \\
Material for CPR available & - & $18(90)^{*}$ & $1(5)$ & - \\
Allergy verified & $1(5)$ & $19(95)^{*}$ & - & - \\
Material for difficult intubation & - & $20(100)^{*}$ & - & - \\
Instrumentals, orthoses and prostheses & - & $20(100)^{*}$ & - & - \\
Material for anaesthesia & - & $20(100)^{*}$ & - & - \\
Valid sterilization of materials & - & $20(100)^{*}$ & - & - \\
Aspirator working & $1(5)$ & $19(95)^{*}$ & - & - \\
Heating system & - & $20(100)^{*}$ & - & - \\
\hline
\end{tabular}


Table 3 - Adherence to the surgical safety checklist during the third verification stage - surgical break $(n=20)$. Curitiba, $\mathrm{PR}, 2012$

\begin{tabular}{lcc}
\multicolumn{1}{c}{ Observed variables } & $\begin{array}{c}\text { Verbal verification } \\
\mathbf{n ( \% )}\end{array}$ & $\begin{array}{c}\text { Non-verbal verification } \\
\mathbf{n}(\%)\end{array}$ \\
\hline Patient identification & - & $20(100)^{*}$ \\
Surgical site marked & $1(5)$ & $19(95)^{*}$ \\
Procedure confirmed & $2(10)$ & $18(90)^{*}$ \\
Antibiotic prophylaxis performed & - & $20(100)^{*}$ \\
Grounding pad connected & - & $20(100)^{*}$ \\
Electrocautery working & $1(5)$ & $19(95)^{*}$ \\
Risk related to positioning & - & $20(100)^{*}$ \\
\hline
\end{tabular}

* $p<0.05$

Source: Research data, 2012.

no count of gauzes, compresses and needles at the end of the procedure. The corresponding items in the checklist, however, were recorded as if they had been verified.

In the procedures where counting did occur, $80 \%(n=$ 16) of the counts ended when the patient was no longer in the room, although the item was checked as if the patient were still in the room. In $40 \%(n=8)$ of the counts, there was no verbal confirmation of the number of surgical instruments that belonged to the hospital. The instruments belonging to the surgeon that were used during the hip and knee replacement surgeries were not checked before or after the procedure.

\section{DISCUSSION}

The results reveal the team's interest in implementing the safe surgery programme. However, important points, such as introducing the team to the patient, surgical break and material counts, were not carried out although the participants were aware they were being observed. Furthermore, in most of the cases, the items were not verbally confirmed, as recommended by the WHO, and they were frequently recorded without an actual verification.

A Spanish study showed that the checklist was used in $80 \%$ of the observed surgical procedures, although the recording of unconfirmed items did highlight problems related to the reliability of these records ${ }^{(15)}$. In addition, the completion of items without the proper verification incurs legal and ethical issues that involve the entire surgical team. It should be noted that situations that endanger the safety of patients gave origin to the objectives presented by the WHO and served as a basis for constructing the checklist ${ }^{(16)}$. The items of the checklist reflect important safety elements, so the non-verification of these items puts patients at risk of adverse events.

The instrument established by the WHO is relevant because in complex environments, such as a surgery unit, the professionals involved must cope with the fallibility of memory and human attention that are frequently neglected, especially in routine activities. The checklist reinforces the recollection of minimum required tasks by making them explicit. It also offers the opportunity to scan items and encourages the discipline of high performance ${ }^{(16)}$. Even before the WHO recommendations were published, the Joint Commission on Accreditation of Hospital Organizations established, in the Universal Protocol, the performance of preoperative verifications that must ensure, among other items, the availability of all the necessary documentation to initiate procedures ${ }^{(17)}$.

In the first stage, there was a statistically significant adherence to the checklist at the patients' floor of origin, which guaranteed that the patients were transported to the operating room in the appropriate conditions for surgery and with the full documentation. However, the title of the instrument for this specific stage is "Reception at the Surgical Unit", which implies that the items should be rechecked when the patient is admitted to the surgical unit. It should be noted that, in the routine of the studied hospital, the nursing professionals were responsible for transporting the patient to the surgical unit. Therefore, any changes to the instrument or item verification routine for this stage could be made at this time.

The items were checked during the verification stage inside the operating room with the patient present and before the induction of anaesthesia. However, this verification was not verbal and did not include the entire team, 
as recommended by the members of the study group on Patient Safety of the $\mathrm{WHO}^{(4)}$. Verbal confirmation reinforces communication, that is, it signals that the professionals present agree with the checked items and therefore hold themselves responsible for patient safety as a group.

The third stage of the checklist should be verified before surgical incision and also comprises the verbal confirmation of all the team members of the items of the corresponding column, as presented in table 3. Moreover, it is a stage in which verbal communication is highly relevant due to the critical nature of the moment immediately before surgical incision. However, the results of this study showed that the surgical break with verbal confirmation was not present in any of the 20 procedures, although the items had been individually checked and verified. In a study conducted during the WHO test pilot, some obstacles were detected that prevent the non-performance of the surgical break. These items include a shortage of nurses, the shyness of the medicine students that prevents them from stopping the procedure and checking the items, and social difficulties ${ }^{(16)}$.

The Joint Commission on Accreditation of Hospital Organizations stipulates that the surgical break should include the verbal verification of the entire team, and that the purpose of the break is to evaluate and ensure that the patient, the site and the procedure are correct, in addition to ensuring that all the documents, equipment and information are accessible ${ }^{(17)}$. Consequently, knowing the reasons for not performing the break can help promote greater adherence to this item, considering that communication problems hinder adherence to safety programmes and the application of the checklist, and contribute to the occurrence of adverse events related to the procedures ${ }^{(18)}$.

In a study that analyzed the answers of 502 orthopaedic surgeons to a questionnaire on the safe surgery protocol, $40.8 \%$ stated they had witnessed surgeries on the wrong patient or on the wrong site; and $25.6 \%$ of these surgeons believed that the lack of communication contributed to the error ${ }^{(19)}$. This finding stresses the importance of verbal confirmation as an error prevention strategy. Verbal communication also reinforces the commitment of the professionals present in the operating room that surgery can be safely initiated in relation to the verified items.

The fourth stage of the checklist should be performed before the patient leaves the operating room. In this step, adherence to item verification in relation to the documentation was observed, although the counting of gauzes, compresses, needles and surgical instruments was not performed. It should be noted that this measure aims to detect the retention of foreign bodies in the surgical cav- ity while the patient is still in the operating room. A study conducted between 2003 and 2006 observed 68 reports of cases of retention of surgical items in patients. Of these statements, 34 were considered near misses, which is when the problem is detected before the end of surgery. The remaining 34 cases consisted of the retention of 23 gauzes or compresses (68\%), 3 needles (9\%), 7 other materials (20\%) and a surgical instrument (3\%). The outcome involved the surgical reintervention of 22 patients, which only reinforces the importance of verification ${ }^{(20)}$.

A similar study showed less adherence to the last stage of the checklist in comparison to the previous stages ${ }^{(15)}$. A tired team and the fact that the surgeon was no longer in the operating room were some of the associated factors ${ }^{(15)}$, which reinforces the idea that the absence of some professionals immediately after surgery hinders completion of the instrument ${ }^{(19)}$.

As a strategy to prevent problems related to checklist application and the lack of commitment of the surgical team, some studies suggest educational actions that break paradigms, such as the hierarchy of the surgeon, improve the communication system and promote a change of culture ${ }^{(15-16)}$. Considering the checklist implementation phase at the studied hospital, the results can support the planning of strategies that contribute to the continuity and improvement of the safe surgery programme at the institution.

\section{CONCLUSION}

It is concluded that although the checklist was used in all the surgeries, there was no significant adherence to the instrument and there was no verbal verification of the items. When the verifications occurred, they were predominantly individual and non-verbal. The data collection technique, which consisted of non-participant observation after the approval of the participants, can be considered a limitation of this study. However, it is also a valid strategy to audit compliance with the institutional protocol.

Considering that the nursing team participates in the various stages of the surgical procedure, the checklist is an important document that records items that are essential for patient safety. This study reports that when this legal document is incorrect or incomplete, it can provide evidence of the quality of care and the carelessness of the nursing team members and the other professionals of the surgical team.

Based on the principle that adherence to the verbal verification of the checklist items is an important safety strategy, the results suggest a range of potential risks to the surgical patient. This study supports the planning of administrative 
and educational actions that ensure the full implementation of the programme at the institution, and the debate on communication and the ethical aspects of care.

\section{口REFERENCES}

1. The World Health Organization. Second Global Patient Safety Challenge "Safe Surgery Saves Lives" [Internet]. Brasilia: OPAS, Anvisa, Ministério da Saúde; 2009 [cited in 2014 sept. 15]. Available at: http://bvsms.saude.gov.br/bvs/ publicacoes/seguranca_paciente_cirurgia_salva_manual.pdf

2. Haynes AB, Weiser TG, Berry WR, Lipsitz SR, Breizat AH, Dellinger EP, et al. The surgical safety checklist to reduce morbity and mortality in global population. New Engl J Med. 2009 [cited 2012 Dec. 18];360(5):491-9. Available at: http:// www.nejm.org/doi/pdf/10.1056/NEJMsa0810119

3. World Health Organization. WHO surgical safety checklist manual implementation 2009: safe surgery saves life [Internet]. Geneva; 2009 [cited 2015 May 02]. Available at: http://whalibdoc.who.int/publications/2009/9789241598590_eng.pdf

4. Fragata JIG. Erros e acidentes no bloco operatório: revisão do estado da arte. Rev Port Saúde Pública. 2010 [cited 2014 ago. 20];Vol Temat(10):17-26. Available at: http://www.elsevier.pt/pt/revistas/revista-portuguesa-saude-publica-323/artigo/erros-e-acidentes-no-bloco-operatorio-revisao-do-13189855

5. Agência Nacional deVigilância Sanitária (BR) [Internet]. Braślia; 2013 [cited 2014 Aug. 20]. Saúde e Anvisa lançam açōes para a segurança do paciente; [aprox. 5 telas]. Avaliable at: http://portal.anvisa.gov.br/wps/content/anvisa+portal/anvisa/ sala+de+imprensa/menu+-+noticias+anos/2013+noticias/ministerio+da+ saude+e+anvisa+lancam+acoes+para+seguranca+do+paciente

6. Freitas MR, Antunes AG, Lopes BNA, Fernandes FC, Monte LC, Gama ZAS. Avaliação da adesão ao checklist de cirurgia segura da OMS em cirurgias urológicas e ginecológicas, em dois hospitais de ensino de Natal, Rio Grande do Norte, Brasil. Cad Saúde Pública. 2014 [cited 2015 April 18];30(1):137-48. Available at: http://dx.doi.org/10.1590/0102-311X00184612

7. Russ S, Rout S, Caris J, Mansell J, Davies R, Mayer E, et al. Measuring variation in use of the WHO surgical safety checklist in the operating room: a multi center prospective cross-sectional study. I Am Coll Surg. 2015 [cited 2015 April 20];220(1):1-11. Available at: http://dx.doi.org/10.1016/jj.jamcollsurg.2014.09.021

8. 8. Russ SJ, Sevdalis N, Moorthy K, Mayer EK, Rout S, Caris J, et al. A qualitative evaluation of the barriers and facilitators toward implementation of the
WHO surgical safety checklist across hospitals in England: lessons from the "Surgical Checklist Implementation Project". Ann Surg. 2015 [cited 2015 April 20];261(1):81-91. Available at: http://www.rcoa.ac.uk/sites/default/files/SurgicalSafetyChecklist.pdf

9. Contandriopoulos AP, Champagne F, Denis JL, Pineault R. Avaliação na área da saúde: conceitos e métodos. In: Hartz ZMA, organizador. Avaliação em saúde: dos modelos conceituais à prática na análise da implantação de programas [Internet]. Rio de Janeiro: FIOCRUZ, 1997 [cited 2015 June 05]. p. 29-47. Available at: http://books.scielo.org/id/3zctt/pdf/hartz-9788575414033-04.pdf

10. Bolfarine H, Bussab WO. Elementos de amostragem. São Paulo: Blucher; 2005.

11. Marconi MA, Lakatos EM. Técnicas de pesquisa: planejamento e execução de pesquisas, amostragens e técnicas de pesquisa, elaboração, análise e interpretação de dados. 7. ed. São Paulo: Atlas; 2010.

12. R Development Core Team. R: a language and environment for statistical computing [Internet]. Vienna: R. Foundation for Statistical Computing; 2011 [cited in 2012 out. 08]. Available at: https://www.r-project.org/

13. Bussab W0, Morettin PA. Estatistica básica. 8. ed. São Paulo: Saraiva; 2013.

14. Maziero ECS. Avaliação do Programa Cirurgia Segura em um hospital de ensino [dissertação]. Curitiba (PR): Programa de Pós-Graduação de Enfermagem, Universidade Federal do Paraná; 2012.

15. Soria-Aledo V, Silva ZA, Saturno PJ, Grau-Polan M, Carrillo-Alcaraz A. Dificultades en la implantación del checklist em los quirófanos de cirugía. Cir Esp. 2012 [cited 2014 August 20];90(3):180-5. Available at: http://www.um.es/calidadsalud/archivos/Soria-Aledo\%20et\%20al.,\%202012.pdf

16. Gawande A. Checklist: como fazer as coisas bem feitas. Rio de Janeiro: Sextante; 2011.

17. Joint Comission Resources (US). Temas e estratégias para liderança em enfermagem: enfrentando os desafios hospitalares atuais. Porto Alegre: Artmed; 2008.

18. Fourcade A, Blache JL, Grenier C, Bourgain LL, Minvielle E. Barriers to staff adoption of a surgical safety checklist. BMJ Qual Saf. 2012 [cited April 20 2013];21(3):191-7. Available at: http://qualitysafety.bmj.com/content/21/3/191.full.pdf-html

19. Motta Filho GR, Silva LFN, Ferracini AM, Bähr GL. Protocolo de cirurgia segura da OMS: o grau de conhecimento dos ortopedistas brasileiros. Rev Bras Ortop. 2013 [cited 2015 Jan. 12];48(6):554-62. Available at: http://www.sciencedirect. com/science/article/pii/S010236161300146X

20. Cima RR, Kollengode A, Garnatz J, Storsveen A, Weisbrod C, Deschamps C. Incidence and characteristics of potential and actual retained foreign object events in surgical patients. J Am Coll Surg. 2008 [cited in 2015 jan. 10];207(1):80-7. Available at: http://www.journalacs.org/article/S1072-7515\%2808\%2900069-0/abstract

\section{Author's address:}

Eliane Cristina Sanches Maziero

Rua Santa Ana, 53, Jardim Fátima

83405-070 Colombo - PR

E-mail: elicris_maziero@yahoo.com.br
Received: 22.02.2015

Approved: 12.08 .2015 